\title{
Физиология PHYSIOLOGY
}

\section{Morphofunctional characterization of rat thymus mast cells after administration of magnesium orotate mechanically activated forms}

\author{
Natalya N. Chuchkova ${ }^{1} \underset{\text { iD }}{ }$, Marina V. Smetanina ${ }^{1}$, Alexei E. Shklyaev ${ }^{1}$, \\ Ksenia A. Pazinenko ${ }^{1}$, Natalya V. Kormilina ${ }^{1}{ }^{(D)}$, Olga M. Kanunnikova ${ }^{2}$ \\ ${ }^{1}$ Izhevsk State Medical Academy, Izhevsk, Russian Federation \\ ${ }^{2}$ Udmurt Federal Research Center of the Ural Branch of the Russian Academy of Sciences, Izhevsk, Russian Federation \\ $\checkmark$ mig05@inbox.ru
}

\begin{abstract}
Annotation. Relevance. The topicality of the work is determined by the wide spread of hypomagnesemia among the people, which makes it necessary to correct it. The aim of the work is to elucidate the cell-mediated response of the thymus mastocytic link to magnesium deficiency and its correction by the mechanoactivated form of magnesium orotate. Materials and Methods. Animals with drug-induced magnesium deficiency (administration of furosemide $30 \mathrm{mg} / \mathrm{kg}$ for 14 days) were administered either the initial preparation Magnerot (Magnerot@), Vervag Pharma, Germany), or its mechanoactivated form. The level of magnesium in the blood was determined by test systems «ARKREY» (Japan). The concentration of magnesium in the thymus tissue was determined by the method of emission spectroscopy with inductively coupled (argon) plasma on an atomic emission spectrometer. Density of mastocytes and the indices of degranulation and granulolosis were calculated on paraffin sections of the thymus after coloration with toluidine blue. Results and Discussion. It was shown that furosemide administration the amount of magnesium decreased in the blood (from 1,75 $\pm 0,08$ to $0,902 \pm 0,18 \mathrm{mmol} / \mathrm{l}, \mathrm{p}<0,05$ ), but increased in the thymus (from $1,6 \pm 0,6$ in the control to $3,7 \pm 1,2 \mathrm{mg} / \mathrm{l}$ ); in the gland tissue, the number of mastocytes of morphotype «A» decreased and the number of mastocytes of morphotype «D», after active degranulation, increased (by 7,1 times, $\mathrm{p}<0,05$ ). The type of mastocyte secretion in hypomagnesemia is represented by the merocrine variant. The administration of the initial magnesium orotate led to an increase in the concentration of magnesium in the blood to $1,15 \pm 0,25 \mathrm{mmol} / \mathrm{l}$, which is $65,7 \%$ of the initial level, the amount of magnesium in the thymus remained elevated $(3,4 \pm 1,1 \mathrm{mg} / \mathrm{l})$, the number of actively degranulating cells (morphotype «D») was increased. Mechanoactivated magnesium orotate restored the concentration of Mg2+ in the blood to 89,1\% (1,56 $\pm 0,18 \mathrm{mmol} / \mathrm{l}$, $\mathrm{p}>0,05$ ) and decreased in the thymus (to $2,3 \pm 0,7 \mathrm{mg} / \mathrm{l}$ ), restored the subpopulation of mastocytes saturated with heparin (type «A»), reduced the number of mastocytes of morphotype «D». Conclusion. The mechanoactivated form of magnesium orotate
\end{abstract}

(C) Chuchkova N.N., Smetanina M.V., Shklyaev A.E., Pazinenko K.A., Kormilina N.V., Kanunnikova O.M., 2021 
has a normalizing effect on the population of thymic mastocytes, shows pronounced immunomodulatory activity, which allows us to consider it as a potential therapeutic agent for clinical testing in the complex therapy of hypomagnesemia and associated immunodeficiency.

Keywords: thymus, mast cells, drug-induced magnesium deficiency, mechanically activated magnesium orotate

Author contributions. Concept and design of the research: Chuchkova N. N., Kanunnikova O.M.; experiment: Pazinenko K.A., Smetanina M.V., Kormilina N.V.; interpretation of results - all authors. Manuscript writing and editing: Chuchkova N.N., Shklyaev A.E., Pazinenko K.A.

Conflicts of interest statement. The author declares no conflict of interest.

Acknowledgements. The authors express their gratitude to the staff of the division of structural phase transformations research center of metallurgical physics and materials science Udmurt Federal research center, Ural branch of RAS, Izhevsk for the preparation of the drug «Magnerot» at the planetary ball mill AGO-2C.

Received 23.03.2021. Accepted 11.05.2021.

For citation: Chuchkova NN, Smetanina MV, Shklyaev AE, Pazinenko KA, Kormilina NV, Kanunnikova OM. Morphofunctional characterization of rat thymus mast cells after administration of magnesium orotate mechanically activated forms. RUDN Journal of Medicine. 2021;25(3):248-255. doi: 10.22363/2313-0245-2021-25-3-248-255

\section{Introduction}

Mast cells are active participants in the regulation of immune homeostasis, which are given active attention in the scientific literature, including recent years [1-3]. A variety of reasons $[4,5]$ is the basis of the immune imbalance in magnesium deficiency, which requires pharmacological correction. Magnesium salts of organic acids are the active substances of most drugs used to correct the condition of hypomagnesemia and its consequences. Magnesium orotate has three isomeric forms that differ by functional groups: nitrogen- and oxygen-containing groups. These groups determine the participation of the orotate anion in biological and biochemical processes, which is accompanied by different therapeutic effectiveness [6]. Obtaining isomers in a stable state is possible using the method of mechanical activation, which results in an improvement in the biological properties of medicines [6, 7]. An important stage in the study of the properties of new or modified already known and used in the clinic (like magnesium orotate) forms of medicines is the analysis of their immune and/or allergic effects on the body. Thus, the aim of the research is to elucidate the cell-mediated reaction of the mast cells of thymus to magnesium deficiency and its correction by the mechanically activated form of magnesium orotate.

\section{Materials and methods}

The work was performed on 50 white rats Rattus norvegicus Berk (vivarium of the Izhevsk State Medical Academy) of both sexes at the age of $2-3$ months, weighing 180-200 grams.

The study was approved by the Committee on Biomedical Ethics of the Izhevsk State Medical Academy (registration N656, from 23.04.2019). The animals were kept in standard vivarium conditions with standard light, a diet, free access to water and physical activity. To eliminate the influence of seasonal circadian dependence, experiments were conducted in the autumn-winter period in the afternoon.

A model of drug-induced deficiency of magnesium with a furosemide load was used for the formation of hypomagnesemia [8]. For this purpose, animals were administered intraperitoneally with a $1 \%$ solution of furosemide (Lasix $\AA$, Aventis Pharma Ltd., India) at a dose of $30 \mathrm{mg} / \mathrm{kg}$ for 2 weeks. Furosemide was discontinued after 14-day administration and the animals were divided into 2 groups: experimental 
group № 1 - received magnesium orotate by gastric catheter; the second experimental group № 2 mechanoactivation form of magnesium orotate, obtained by mechanical activation. The dose of the drug (initial and mechanoactivated) was $50 \mathrm{mg} / \mathrm{kg}$ of elemental magnesium, which corresponds to the therapeutic dose of magnesium orotate used for the treatment and prevention of hypomagnesemia. The time duration of the course of administration of magnesium preparations was 2 weeks.

The mechanoactivated drug was prepared in the Department of Structural and Phase Transformations of the Scientific Center for Metallurgical Physics and Materials Science, Udmurt Federal Research Center of the Ural Branch of the Russian Academy of Sciences (Izhevsk, Russia). The mechanoactivated form was prepared of the initial preparation Magnerot (Vervag Pharma GmbH and Co., Germany) in a spherical planetary mill AGO-2C at a drum speed of $600 \mathrm{rpm}$, power density is $2 \mathrm{~kJ} / \mathrm{g}$. The temperature of the drum walls during mechanical activation did not exceed $60{ }^{\circ} \mathrm{C}$ due to forced water cooling. Mechanical activation does not introduce foreign impurities into the processed substance, which may appear when the balls and the walls of the grinding vessels are worn [6].

Histological investigation of the thymus was performed in intact animals and animals with hypomagnesemia (comparison group) and on day 14 after the end of the administration of drugs. The thymus was fixed in $10 \%$ formalin, poured into a paraffin medium for filling (HISTOMIX), serial sections with a thickness of $5-7$ microns were prepared, stained with hematoxylin and eosin for the analysis of the general structure of the organ, toluidine blue (BioVitrum, Russia), and Brachet method — for the detection of mast cells.

The number of cells was calculated per $100 \mu \mathrm{m} 2$ when the magnification of the microscope will be 400 times. Functional status of mast cells was evaluated by degree of degranulation, releasing 4 types of cells [9]: «A» — is mast cells with densely filled with indistinguishable granules and the nucleus; «B» — mast cells with discernable individual grains and is not fully masked by the nucleus; «C» — mast cells with a well- defined granules within and around cells, and a distinct nucleus; «D» - devastated mast cells with single granules inside and scattered granules around the cell. Individual mast cells populations were characterized at $\times 1500$. Secretory indices (relative units) of mast cells was calculated by the formula: index of degranulation (ID) $\mathrm{ID}=\mathrm{C} /(\mathrm{A}+\mathrm{B}+\mathrm{C}+\mathrm{D})$; index granulolysis (IG): $I G=D /(A+B+C+D)$; index total granulolysis (ITG): ITG $=(C+D) /(A+B+C+D)$; index saturation heparin (ISH): $\mathrm{ISH}=(\mathrm{A}+\mathrm{B}) /(\mathrm{C}+\mathrm{D})$ [9], where «A», «B», «C», «D» morphofunctional types (morphotypes) of mast cells.

The blood test for the magnesium level was performed on the equipment and test systems of the company «ARKREY» (Japan). The concentration of magnesium in the tissue of thymus was determined by inductively coupled (argon) plasma emission spectroscopy on an atomic emission spectrometer Spectroflame Modula S (Spectro Analytical Instruments GmbH, Germany).

All procedures were carried out under strictly controlled conditions, the material from the experimental and control animals of each series was processed simultaneously. Experiments on animals were conducted in accordance with the Geneva Convention «International Guiding principles for Biomedical Research Involving Animals» (Geneva, 1990) and the Helsinki Declaration (1975).

Statistical processing of the material was carried out using the application software package «STATISTICA $10.0 »$. The arithmetic mean $(\mathrm{M})$ and the standard error of the mean (m) were calculated. The $95 \%$ level of statistical significance of the differences in the results of the study was used. Statistical analysis was performed according to the methods used in medical and biological statistics.

\section{Results and discussion}

Magnicificent status in experimental rats is characterized by a decrease in the concentration of magnesium in serum 1,94 times (from 1,75 $\pm 0,08$ to of $0,902 \pm 0,18 \mathrm{mmol} / \mathrm{L}, \mathrm{p}<0,05$ ) and increase in the concentration of magnesium in the thymus 2,3 
times (from 1,6 $\pm 0,6$ in the control to $3,7 \pm 1,2 \mathrm{mg} / \mathrm{l}$ at hypomagnesemia). The number of mast cells in the thymus in hypomagnesemia increases slightly and is 2,13 $\pm 1,60 \mathrm{pcs} /$ unit area, but, in comparison with the control parameters $(1,97 \pm 0,56 \mathrm{pcs} /$ unit area, $\mathrm{p}<0,1$ ), does not change significantly. Mast cells in hypomagnesemia are in a state of active degranulation, concentrated near dilated vessels, with signs of sludge. Morphofunctional types of mast cells and secretion indices are presented in Table 1.

Table 1

Morphofunctional types of mast cells and secretion indices in animals with hypomagnesemia and administration of various forms of magnesium orotate

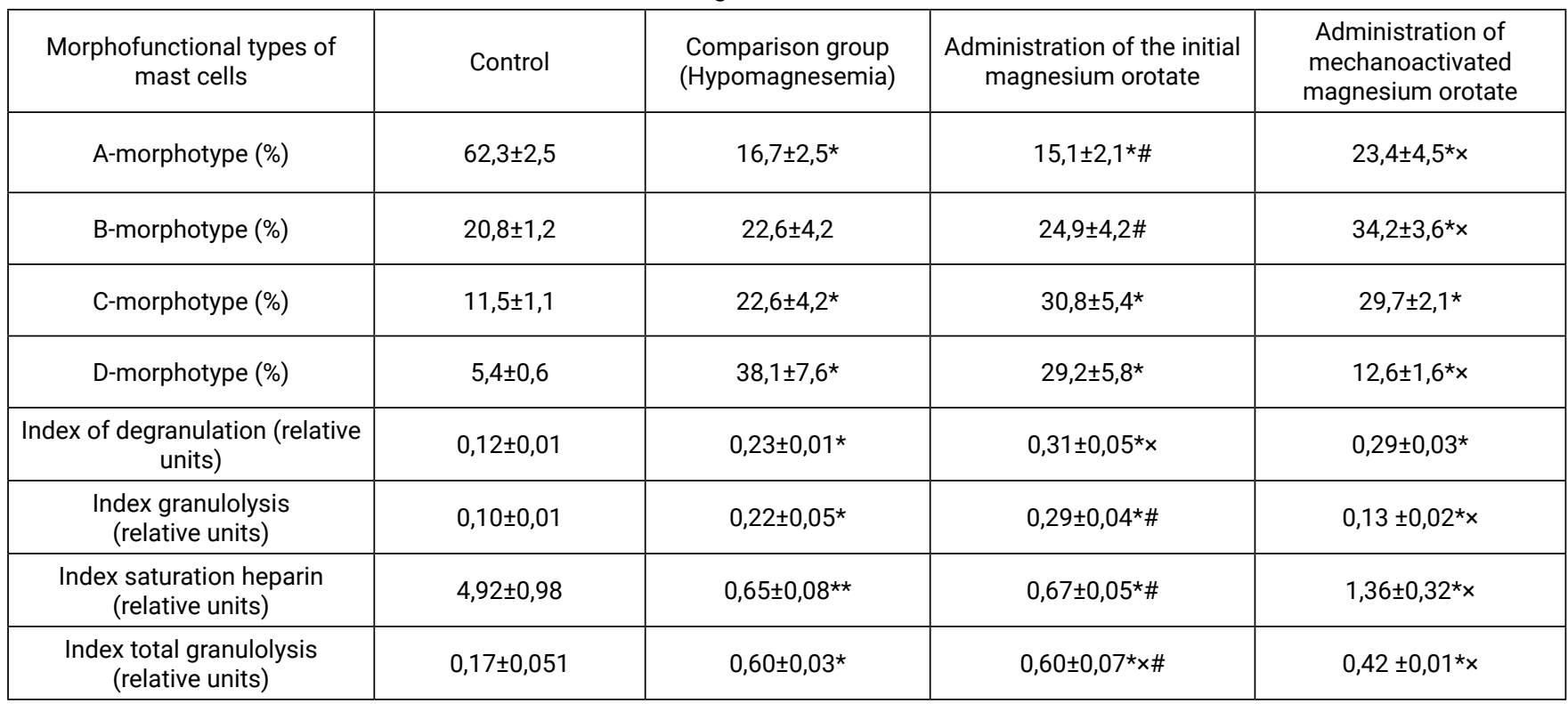

Comment: the differences were significant at $p<0,05$ in comparison with: * - with intact control, $x$ - with the hypomagnesemia group; \#- between the groups with the administration of initial and mechanoactivated magnesium orotate

There is a reorganization of the morphofunctional types of mast cells in the thymus with hypomagnesemia in compared to the control. Thus, the number of A-morphotype mast cells filled with granules decreases by 3,7 times; an especially sharp increase (by 7,1 times, $\mathrm{p}<0,05$ ) in the number of D-morphotype cells emptied, after active degranulation, representing shadow cells. In mast cells, the heparin saturation index was sharply reduced (by 7,6 times, $\mathrm{p}<0,05$ ). The index of total granulolysis (reflects the merocrine type of secretion) and the index of degranulation (apocrine secretion) in animals with hypomagnesemia are increased: index total granulolysis - 3,5 times, index total granulolysis 1,9 times compared to the control, which reflects the active secretory reaction of mast cells in response to the formation of magnesium deficiency. The ratio of the types of secretion in hypomagnesemia is shifted towards significantly the predominance of the merocrine variant and is 3:1 (merocrine: apocrine).

The administration of the initial magnesium orotate leads to an increase in the concentration of magnesium in the blood to $1,15 \pm 0,25 \mathrm{mmol} / \mathrm{l}$, which is $65,7 \%$ of the initial level, the amount of the element in the thymus remains elevated and is comparable to the hypomagnesemia comparison group - 3,4 $\pm 1,1 \mathrm{mg} / \mathrm{l}$. In the thymus of animals of this experimental group, the number of mast cells per unit area is increased and is $3,7 \pm 0,81$ ( 1,7 times more than in hypomagnesemia, $\mathrm{p}<0,05)$. The number of cells of the A-morphotype filled with heparin granules is reduced by 4,1 times, the number 
of actively degranulating cells (C-morphotype), shadow cells (D- morphotype) is generally $60 \%$. The degranulation index was increased by 2,6 times, the granulolysis index is by 2,9 times in comparison with the intact control $(p<0,05)$. Ratio of secretion types (merocrine: apocrine) is 1,9: 1 (in the intact control 1,5:1). Mast cells are mainly distributed in the connective-tissue compartment of the organ, are densely located in the capsule, in the interlobular partitions, there are many of them near the vessels, only rarely found in the thymus tissue.

Mechanoactivated magnesium orotate restores the concentration of $\mathrm{Mg} 2+$ in the blood 2 weeks after administration to $89,1 \%(1,56 \pm 0,18 \mathrm{mmol} / \mathrm{l}$, $\mathrm{p}>0,05$ as compared to the control) and reduces it in the thymus to $2,3 \pm 0,7 \mathrm{mg} / \mathrm{l}$ (lower than in the group with hypomagnesemia, but higher than in the control animals). The number of mast cells in the thymus is $5,8 \pm 1,11$ pcs per $100 \mathrm{~mm} 2$, which is 2,9 times higher than the control parameters $(p<0,05)$. However, the ratio of individual morphofunctional cell phenotypes is more favorable than with the administration of initial magnesium orotate: cells saturated with heparin (A-morphotype) begin to recover, they are 1,5 times more than in the experimental group with initial magnesium orotate. The number of «empty» cells with the absence of biologically active substances of D-morphotype cells significantly decreases (2,3 times, $\mathrm{p}<0,05)$ compared to initial magnesium orotate group (Table.1), which may indicate the beginning of the recovery of the mast cells population. The heparin saturation index begins to increase 2,1 times and the granulolysis index is restored. In the thymus of animals with the administration of mechanoactivated magnesium orotate, in contrast to all the previously described groups, the distribution of mast cells within the structural zones of the organ is markedly different. Mast cells and separate granules are located not only along of the organ capsule, but also around the medullary substance of thymus gland, form chains of cells, occur in the area of the cortico-medullary border and even inside the medullary substance. The heterogeneity of the location of mast cells populations was revealed: B-morphotype are more often present in the tissue (a transitional variant, the cells are filled with granules of biologically active substances), whereas in the septa, subcapsules - mainly cells of the C-morphotype. Ratio of secretion types (merocrine: apocrine) with the administration of mechanoactivated magnesium orotate is leveled, amounting to $1,4: 1$, which almost corresponds to the control index $(1,5: 1)$.

Thus, as a result of the experiment, it was found out that, firstly, the restoration of the concentration of magnesium in the blood and thymus was observed only with the administration of mechanoactivated magnesium orotate. Secondly, all experimental groups (hypomagnesemia, initial magnesium orotate, mechanoactivated magnesium orotate) are characterized by a pronounced reaction of the mastocytic population of the thymus, which is manifested in quantitative (an increase in the pool of mast cells and the number of morphotypes of mast cells with signs of active degranulation) and qualitative (a change in the type of secretion of biologically active products and intra-thymic cell location) data. A more favorable morphologically and functionally balanced response of the mast cells population is observed in a group of animals with the administration of mechanoactivated magnesium orotate.

Mast cells have pleiotropic and polyvalent functions, which make them universal cells that can quickly adapt to changes in the microenvironment [1, $10,11]$, provide tissue homeostasis, participate in the processes of differentiation and migration of thymocytes, and determine their role in angiogenesis and regulation of anti-inflammatory and immune activity [3, 12].

The cellular-tissue response of the mastocytic link of the thymus to the administration of mechanoactivated magnesium orotate is associated with a change in the activity of the drug, achieved as a result of mechanical activation of the drug. So, the particle size of magnesium orotate decreases by mechanical activation (mechaactivated the drug is represented by particles of about $60 \mathrm{~nm}$, whereas the initial drug is a large conglomerates, measured in $\mu \mathrm{m})[6,13]$, the degree of amorphization of the compound increases and the speed of dissolving it in aqueous solutions [13] which leads to the increase in volume of the substance is supplied to the blood through the membrane of the 
epithelium of the intestinal wall. It is known that no more than $40 \%$ of the magnesium received orally is absorbed in the intestine, and an increase in the volume of the received drug can increase the characteristics of the therapeutic effect of the drug. X-ray photoelectron spectroscopy of magnesium orotate in the initial state and after mechanical activation revealed the presence of four active functional groups in the mechanoactivated magnesium orotate molecule $[6,12]$, which provides a greater number of binding sites on the cell membrane, and this, in turn, ensures active interaction with the plasmolemma and the entry of magnesium orotate molecules into the target cells.

Mechanoactivated magnesium orotate is more active in vitro [14] and changes the ratio of CD68+ macrophages in the thymus [15]. It is important that the state of the compounds achieved by processing in high-energy devices under the regimes does not lead to destruction or change in the crystal or isomeric structure of the substance $[6,16]$. In the magnesium orotate molecule, not only magnesium plays a significant biological role, but also the orotic acid anion, which is an intermediate in the biosynthesis of pyrimidine and provides a wide range of usefull effects [17-19].

\section{Conclusion}

The mechanoactivated form of magnesium orotate has a normalizing effect on the population of thymic mastocytes, shows pronounced immunomodulatory activity, which allows us to consider it as a potential therapeutic agent for clinical testing in the complex therapy of hypomagnesemia and associated immunodeficiency.

\section{References}

1. Elieh Ali Komi D, Grauwet K. Role of Mast Cells in Regulation of T Cell Responses in Experimental and Clinical Settings. Clin Rev Allergy Immunol. 2018;54(3):432 - 445. doi: 10.1007/s12016017-8646-z

2. Forsythe P. Mast Cells in Neuroimmune Interactions. Trends Neurosci. 2019;42(1):43—55. doi:10.1016/j.tins.2018.09.006

3. Ribatti D. A new role of mast cells in arteriogenesis. Microvasc Res. 2018;(118):57—60. doi: 10.1016/j.mvr.2018.02.008
4. Castiglioni S, Cazzaniga A, Locatelli L, Maier JA. Burning magnesium, a sparkle in acute inflammation: gleams from experimental models. Magnes Res. 2017;30(1):8-15. doi: 10.1684/mrh.2017.0418.

5. Shahi A, Aslani S, Ataollahi M, Mahmoudi M. The role of magnesium in different inflammatory diseases. Inflammopharmacology. 2019;27(4):649—661. doi:10.1007/s10787-019-00603-7

6. Karban OV, Kanunnikov MM, Chuchkova NN, Savinova NV, Mukhgalin VV. Structure, Physical, Chemical and Biological Properties of Magnerot Nanoscale Drag. Kodolov VI, Korepanov MA, editors. Applied Mathematical models and experimental approaches in chemical science. Apple Academic press Inc. 2017.

7. de Melo CC, da Silva CC, Pereira CC, Rossa PC, Ellena J. Mechanochemistry applied to reformulation and scale-up production of Ethionamide: Salt selection and solubility enhancement. Eur J Pharm Sci. 2016;(81):149-156.

8. Spasov AA, Iezhitsa IN, Kharitonova MV, Zheltova AA. Violation of the exchange of magnesium and potassium and its pharmacological correction. OSU Bulletin. 2011; 5(134):131-135.

9. Lindner DP, Poberi IA, Raskin MJ. Morphometric analysis of populations of mast cells. Archives of pathology. 1980;62(6):60_64.

10. Cardamone C, Parente R, Feo GD, Triggiani M. Mast cells as effector cells of innate immunity and regulators of adaptive immunity. Immunol Lett. 2016;(178):10_14. doi: 10.1016/j.imlet.2016.07.003.

11. Chuchkova NN, Smetanina MV, Kormilina NV, Kanunnikova OM, Pazinenko KA. Cellular composition of the thymus in drug-induced magnesium deficiency. RUDN Journal of Medicine. 2020;24(1):85-92. doi: 10.22363/2313-0245-2020-24-1-85-92

12. Theoharides TC, Tsilioni I, Conti P. Mast Cells May Regulate The Anti-Inflammatory Activity of IL-37. Int J Mol Sci. 2019;20(15):3701. doi: 10.3390/ijms20153701

13. Kanunnikova OM, Karban OV, Chuchkova NN, Mukhgalin VV, Gilmutdinov FZ, Komissarov VB. Preparation, physical-chemical and biological properties of tautomeric nanoforms of the preparation «magnerot». Nanotechnologies: science and production. 2014;4(31):80-88.

14. Chuchkova NN, Kanunnikov MM, Smetanina MV, Komissarov VB, Solov'ev AA. Comparative study of the effectiveness of magnesium orotate tautomers for magnesium deficiency compensation. Part I. Effect of magnesium orotate tautomers on isolated cells of laboratory animals and humans. Ural Medical Journal. 2018;159(4):141-146. doi: 10.25694/URMJ.2018.04.056

15. Chuchkova NN, Tukmacheva KA, Smetanina MV, Kanunnikova OM, Sergeev VG, Chuchkov VM. Characteristics of the population of the rat thymus CD68+ cells in response to tautomeric forms of magnesium orotate Introduction under Simulated Magnesium Deficiency. Journal of Anatomy and Histopathology. 2019;8(1):82-88. doi: 10.18499/2225-7357-2019-8-1-82-88

16. de Cássia Zaghi Compri J, Andres Felli VM, Lourenço FR, Takatsuka T, Fotaki N, Löbenberg R, et al. Highly water-soluble orotic acid nanocrystals produced by high-energy milling. J Pharm Sci. 2019;108(5):1848-1856. doi: 10.1016/j.xphs.2018.12.015

17. Gromova OA, Torshin IYu, Kalacheva AG. Metabolomic compendium for magnesium orotate. Effective pharmacotherapy. 2015;44:14-26.

18. Beiter T, Hudemann J, Burgstahler C, Nieß AM, Munz B. Effects of extracellular orotic acid on acute contraction- 
induced adaptation patterns in C2C12 cells. Mol Cell Biochem. 2018;448(1-2):251-263. doi:10.1007/s11010-018-3330-z.

19. Shimamoto S, Nakamura K, Tomonaga S, Furukawa S, Ohtsuka A., Ijiri D. Effects of Cyclic High Ambient Temperature and
Dietary Supplementation of Orotic Acid, a Pyrimidine Precursor, on Plasma and Muscle Metabolites in Broiler Chickens. Metabolites. 2020;10(5):189. doi: 10.3390/metabo10050189. PMID: 32408619; PMCID: PMC7281580.

\title{
Морфофункциональная характеристика мастоцитов тимуса крыс при введении механоактивированной формы магния оротата
}

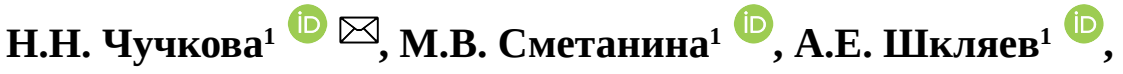 \\ К.А. Пазиненко $^{(i D}$, Н.В. Кормилина ${ }^{(D)}$, О.М. Канунникова ${ }^{2}$ \\ ${ }^{1}$ Ижевская государственная медицинская академия, г. Ижевск, Российская Федерация \\ ${ }^{2}$ Удмуртский федеральный исследовательский центр Уральского отделения Российской академии наук, \\ г. Ижевск, Российская Федерация \\ $\checkmark$ mig05@inbox.ru
}

Анатация. Актуальность. Гипомагнезиемия широко распространена среди населения, что вызывает необходимость ее коррекции. Цель работы - выяснение клеточно-опосредованной реакции мастоцитарного звена тимуса на дефицит магния и его коррекцию механоактивированной формой магния оротата. Материалы и методы. Животным с лекарственно-обусловленным дефицитом магния (введение фуросемида 30 мг/кг 14 дней) с целью коррекции гипомагнезиемии водили либо исходный препарат Магнерот (Magnerot $\odot$, Верваг Фарма ГмбX и Ко, Германия), либо его механоактивированную форму. Уровень магния в крови определяли тест-системами «ARKREY» (Япония). Концентрацию магния в ткани тимуса определяли методом эмиссионной спектроскопии с индуктивно связанной (аргоновой) плазмой на атомно-эмиссионном спектрометре. Плотность расположения мастоцитов на единицу площади, индексы дегрануляции и гранулолизиса рассчитывали на парафиновых срезах тимуса после окраски толуидиновым синим. Результаты и обсуждение. Было показано, что при фуросемидной нагрузке количество магния снижалось в крови (с $1,75 \pm 0,08$ до 0,902 $\pm 0,18$ ммоль/л, $\mathrm{p}<0,05)$, но повышалось в тимусе (с $1,6 \pm 0,6$ в контроле до $3,7 \pm 1,2$ мг/л); в ткани железы снижалось количество мастоцитов типа «A» и повышалось (в 7,1 раза, $\mathrm{p}<0,05)$ количество мастоцитов типа «D», опустошенных, после активной дегрануляции. Тип секреции мастоцитов при гипомагниемии представлен мерокриновым вариантом. Введение исходного магния оротата приводило к повышению концентрации магния в крови до 1,15 $\pm 0,25$ ммоль/л, что

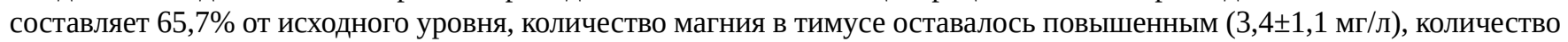
активно дегранулирующих клеток (тип «D») повышено. Механоактивированный магния оротат восстанавливал кон-

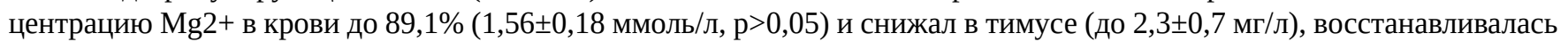
субпопуляция мастоцитов, насыщенных гепарином (тип «А»), снижалось количество мастоцитов типа «D». Bыводы. Механоактивированная форма магния оротата оказывает нормализующее действие на популяцию мастоцитов тимуса проявляет выраженную имуномодулирующую активность, что позволяет рассматривать ее в качестве потенциального терапевтического агента для клинической апробации в комплексной терапии гипомагнезиемии и связанного с ней иммунодефицитного состояния.

Ключевые слова: тимус, мастоциты, лекарственно-обусловленный дефицит магния, механоактивированный магния оротат

Вклад авторов. Концепция и дизайн исследования: Чучкова Н.Н., Канунникова О.М.; эксперимент: Пазиненко К.А., Сметанина М.В., Кормилина Н.В.; интерпретация результатов - все авторы. Подготовка и редактирование рукописи: Чучкова Н.Н., Шкляев А.Е., Пазиненко К.А. 
Информация о конфликте интересов. Авторы заявляет об отсутствии конфликта интересов.

Благодарности. Авторы выражают благодарность сотрудникам отдела структурных фазовых превращений научно-исследовательского центра металлургической физики и материаловедения Удмуртского федерального исследовательского центра УрО РАН (г. Ижевск) за подготовку препарата «Магнерот» на планетарной шаровой мельнице АГО-2С.

Поступила 23.03.2021. Принята 11.05.2021.

Для цитирования: Chuchkova N.N., Smetanina M.V., Shklyaev A.E., Pazinenko K.A., Kormilina N.V., Kanunnikova O.M. Morphofunctional characterization of rat thymus mast cells after administration of magnesium orotate mechanically activated forms // Вестник Российского университета дружбы народов. Серия: Медицина. 2021. Т. 25. № 3. С. 248-255. doi: 10.22363/23130245-2021-25-3-248-255

Corresponding author: Natalya Nikolaevna Chuchkova — PhD MD, professor, head of the Department of medical biology of the Izhevsk State Medical Academy. 426056, Izhevsk, Kommunarov str., 281, Russian Federation. E-mail: mig05@inbox.ru Chuchkova N.N. ORCID 0000-0001-7777-6825

Smetanina M.V. ORCID 0000-0002-1801-5353

Shklyaev A.E. ORCID 0000-0003-4479-508X

Pazinenko K.A. ORCID 0000-0002-3390-4343

Kormilina N.V. ORCID 0000-0002-2885-5882

Kanunnikova O.M. ORCID 0000-0001-8386-3300

Ответственный за переписку: Чучкова Наталья Николаевна - д.м.н., профессор, заведующая кафедрой медицинской биологии Ижевской государственной медицинской академии. Российская Федерация, 426034, г. Ижевск, ул. Коммунаров, д.281. E-mail: mig05@inbox.ru

Чучкова Н.H. SPIN-код 7291-0160; ORCID 0000-0001-7777-6825

Сметанина M.B. SPIN-код 9437-0083; ORCID 0000-0002-1801-5353

Шкляев A.E. SPIN-код 3537-8929; ORCID 0000-0003-4479-508X

Пазиненко K.A. SPIN-код 4421-9206; ORCID 0000-0002-3390-4343

Кормилина Н.B. SPIN-код 4072-0220; ORCID 0000-0002-2885-5882

Канунникова O.M. SPIN-код: 1307-9370; ORCID 0000-0001-8386-3300 